\title{
FOLIAR SPRAY SURPASSES SOIL APPLICATION OF POTASSIUM FOR MAIZE PRODUCTION UNDER RAINFED CONDITIONS
}

\author{
Abid ALI ${ }^{I^{*}}$, Mozammil HUSSAIN ${ }^{2}$, Hafiz Saqib HABIB ${ }^{3}$, Touseef Taj KIANI ${ }^{2}$, \\ Muhammad Abbas ANEES ${ }^{l}$, Muhammad Abdul RAHMAN ${ }^{3}$ \\ ${ }^{1}$ PMAS- Arid Agriculture University Rawalpindi, Department of Agronomy, PAKISTAN \\ ${ }^{2}$ National Agriculture Research Centre, Crop Sciences Institute, Maize, Sorghum, Millet and Fodder \\ Program, Islamabad, PAKISTAN \\ ${ }^{3}$ PMAS- Arid Agriculture University Rawalpindi, Department of Agricultural Economics, PAKISTAN
}

*Corresponding author: abid.aayan.ali@gmail.com

Received: 21.10 .2015

\begin{abstract}
This field experiment was performed to evaluate the efficiency of potassium (K) foliar spray against soil application on hybrid maize. Treatments were: control, soil applied $75 \mathrm{~kg} \mathrm{~K}_{2} \mathrm{O}$ ha $^{-1}$, foliar spray $1 \% \mathrm{~K}_{2} \mathrm{O}$, foliar spray $2 \% \mathrm{~K}_{2} \mathrm{O}$, foliar spray $3 \% \mathrm{~K}_{2} \mathrm{O}$, fertigation $75 \mathrm{~kg} \mathrm{~K}_{2} \mathrm{O} \mathrm{ha}^{-1}$, and split application in soil $75 \mathrm{~kg} \mathrm{~K}_{2} \mathrm{O}$ $\mathrm{ha}^{-1}$. Potassium foliar sprays increased yield and its components as well as grain quality attributes greater than that with soil application, splitting or fertigation. The highest biological and grain yield were 15.0 and $8.08 \mathrm{t}$ $\mathrm{ha}^{-1}$, respectively under foliar treatment of $3 \% \mathrm{~K}_{2} \mathrm{O}$, followed by $2 \% \mathrm{~K}_{2} \mathrm{O}$ foliar spray. Greater net benefit and benefit cost ratio were with foliar application. Foliar spray of potassium $3 \%$ concentration was more efficient for increasing growth and yield of maize crop as compared to soil application and fertilization of potassium fertilizer.
\end{abstract}

Keywords: Crop growth rate, economic returns, fertigation, leaf area index, net assimilation rate, Zea mays $\mathrm{L}$.

\section{INTRODUCTION}

Among the cereals, maize (Zea mays L.) ranks third after wheat and rice crops, providing nutrition to humans as well as livestock and poultry. It constitutes an important source of carbohydrates, proteins, vitamin-B and minerals (Witt and Pasuquin, 2007). It is used in the form of bread, cake and porridge in many parts of Asia, Africa and America (Bukhsh et al., 2003). Maize grain contains (in per cent) about 71 starch, 9 protein, 4.5 oil, 8.5 fiber and 7 ash (Hurburgh 1989; Chaudhary 1993). Average grain yield in the world is 1.59 times greater than Pakistan due to high temperature and abiotic stresses such as drought, salinity and low temperature (Anonymous, 2006).

Potassium is an important nutrient for improving the crop yield per unit area. Potassium is vital for physiological processes, water availability, photosynthesis, assimilate transport and enzyme activation with a direct effect on crop production. Potassium deficiency significantly reduces the leaves number and size of individual leaf and as a result photosynthetic activity of the plant was affected (William, 2008). Potassium limits the crop water requirement during drought conditions because $\mathrm{K}$ has a dominant role in the opening and closing of stomata, through which transpiration occurs from the leaves and $\mathrm{CO}_{2}$ enters into leaf tissues. If $\mathrm{K}$ is inadequate, the stomatal activity decreases and transpiration loss increases. Grain yield increases by enhancing the uptake of potassium under the arid condition (Damon and Rengel, 2008).

Traditionally, potassium fertilizer directly are applied to soil gets fixed with clay minerals and becomes unavailable to crop plants (Ali et al., 2005b). Generally, soils have large capacity to provide $\mathrm{K}$ to crop plants under normal conditions (Ranjha et al., 1990), but increase in cropping intensity, extensive removal of straw from the field, excessive use of tube well water and introduction of high yielding hybrid varieties have resulted in considerable exhaust of soil K (Malik et al., 1989).

Ordinarily, the soils are deficient in nitrogen and phosphorus, whereas potassium deficiency in some areas is up to $45 \%$. But due to intensive and continuous growing of high fertilizer requiring crops (rice, potato and sugarcane), use of unsuitable irrigation water from tube wells, imbalanced fertilizer use and low organic matter may lead to potassium unavailability to crop plants (Mengal and Kirkby, 1987). Moreover, the price of K fertilizers is getting higher and becoming unaffordable by 
farmers (NFDC, 2005). Consequently, foliar application of potassium is more suitable, target oriented and economical technique for increasing the fertilizer use efficiency and grain yield over soil application (Farooqi et al., 2012; Eichert and Burkhardt, 2001). The aforesaid issues of $\mathrm{K}$ availability compel to explore some ways to enhance the $\mathrm{K}$ use efficiency. Therefore, this research work was designed with the objective to elaborate the efficiency and economic benefits of foliar spray for maize (Zea mays L.) production in relation to soil application of potassium under rainfed conditions.

\section{MATERIALS AND METHODS}

\section{Experimental}

This field experiments were conducted under rain-fed conditions at National Agriculture Research Centre, Islamabad during the month of April, 2012 and 2013. Maize hybrid-2704 was sown in this field research. The treatments were allocated to different experimental units in a randomized complete block design (RCBD) with three replications. Seed bed was prepared by ploughing 3 times with tractor mounted cultivator, followed by planking. The hybrid maize was sown in lines by keeping row to row distance $75 \mathrm{~cm}$ and plant to plant distance 20 $\mathrm{cm}$. Sowing was done in lines with dibbler. Seed rate was $25 \mathrm{~kg} \mathrm{ha}^{-1}$ with each plot size of $12 \mathrm{~m}^{2}(4 \mathrm{~m} \mathrm{~L} \times 3 \mathrm{~m} \mathrm{~W})$. Potassium was applied as potassium sulphate $\left(\mathrm{K}_{2} \mathrm{SO}_{4}\right)$. Recommended dose of nitrogen and phosphorus were applied before sowing at the concentration of 120 and 90 $\mathrm{kg} \mathrm{ha-1}$, respectively, to all the treatments. Foliar applications of $\mathrm{K}_{2} \mathrm{O}$ at 1,2 and $3 \%$ concentration (equivalent to $4.3,8.6$ and $13.0 \quad \mathrm{~kg}^{-1} \mathrm{ha}_{2} \mathrm{SO}_{4}$ respectively), were used for spray. Foliar applications of potassium were done at 40 and 65 days after sowing (DAS), respectively.

Experiment comprised of seven treatments as: control (no potassium), soil application of potassium @ $75 \mathrm{~kg} \mathrm{ha}^{-}$ ${ }^{1}$, foliar spray @ $1 \% \mathrm{~K}_{2} \mathrm{O}$, foliar spray @ 2\% $\mathrm{K}_{2} \mathrm{O}$, foliar spray@3\% $\mathrm{K}_{2} \mathrm{O}, \mathrm{K}$ fertigation @ $75 \mathrm{~kg} \mathrm{ha}^{-1}$, and split soil application of potassium as $1 / 2$ at sowing and $1 / 2$ at flowering. Two years data were subjected to analysis of variance using Statistix 8.1 software. Data regarding agro morphological, physiological and quality traits were recorded by using standard procedures as in the following paragraphs.

\section{Data collection}

Five plants were randomly selected at crop maturity from each plot to measure the plant height, 1000-grain weight, grain number per row, grain weight per ear and then averaged. Days to 50 per cent pollen shedding was made for individual entries at the tassel emergence and data were noted on the dates when half of the plants in individual entries started dehiscence. Days were calculated by subtracting the half population completing dehiscence from the date of sowing. Data on silking were recorded in the same manner that was employed for pollen shed except that an ear with single silk emergence was given consideration. For grain yield, all maize plants were harvested from each plot, sun dried and threshed manually to measure the grain yield per plot in $\mathrm{kg} \mathrm{ha}^{-1}$. Biological yield was determined as whole plant material from each plot was harvested from ground level manually, dried and then converted into $\mathrm{kg} \mathrm{ha}^{-1}$.

Photosynthesis and transpiration rate were measured in five plants randomly selected from each plot by using the instrument Infra Red Gas Analyzer (IRGA) LC-pro plus, and the reading was averaged.

Crop growth rate (CGR) was obtained by (Hunt et al., 2002) as:

$$
C G R=\frac{\mathrm{w} 2-\mathrm{w} 1}{\mathrm{~T} 2-\mathrm{T} 1}
$$

Where, $W$ is aboveground plant biomass $(\mathrm{g})$ at $\mathrm{T}_{1}$ and $\mathrm{T}_{2}$ days after crop sowing.

Net assimilation rate (NAR) was calculated by the following formula:

$$
N A R=\frac{\mathrm{TDM}}{\mathrm{LAD}}
$$

Where, $\mathrm{TDM}=$ Total dry matter $\mathrm{LAD}=$ Leaf area duration

$$
L A D=\frac{(\mathrm{LAI} 1+\mathrm{LAI} 2) \times(\mathrm{T} 2-\mathrm{T} 1)}{2}
$$

$\mathrm{LAI}_{1}=$ Leaf area index at $\mathrm{t}_{1}$

$\mathrm{LAI}_{2}=$ Leaf area index at $\mathrm{t}_{2}$

Leaf area index (LAI) was calculated by the following formula:

$$
L A I=\frac{\text { Leaf area }}{\text { Land area }}
$$

Protein contents of maize grain were analyzed by Kjeldhal method. Grain starch contents were determined through the method given by (Juliano, 1991).

\section{Economic analysis}

Total cost of production of maize included the expenses on seed, soil preparation, sowing and all other agronomic operations. Net benefit, gross revenue and benefit cost ratio were derived from the data collected.

\section{Statistical analysis}

All data were subjected to analysis of variance, and the treatment means were compared by LSD at 5 per cent level of probability (Montgomery, 2001).

\section{RESULTS AND DISCUSSION}

\section{Plant growth attributes}

Height of the hybrid maize was significantly affected by different potassium treatments but year's affect was non-significant (Table 1). Higher plant height was recorded in all foliar $\mathrm{K}$ treatments as compared to soil application and fertigation of potassium. The highest plant 
height was $187 \mathrm{~cm}$ under $3 \% \mathrm{~K}_{2} \mathrm{O}$ foliar spray which was at par with $2 \% \mathrm{~K}_{2} \mathrm{O}$ foliar treated plot. The lowest plant height $(121 \mathrm{~cm})$ was obtained in control treatment. Maize plant exhibited fixed number of nodes but foliar potassium treatments increased the intermodal length, as a result plant height was increased and more accumulation of photosynthates took place, which lead to higher grain yield per unit area (Figure 1). Significant differences among treatments were also noted for days taken to 50 per cent pollen shedding and $50 \%$ silking which were at the lowest (53.0 and 54.7, respectively) under $3 \% \mathrm{~K}_{2} \mathrm{O}$ foliar spray. More number of days were noted for 50 per cent pollen shedding and 50 per cent silking (60 and 61.3, respectively) in control (no potassium), followed by soil applied K fertigation. Amal et al. (2011) reported that foliar application of potassium and urea @ 2\% at 65, 90, and 115 DAS increased the plant height, made faster pollen shedding and silk maturity of wheat and maize due to higher uptake of $\mathrm{K}$ foliar through application. The early pollen shedding increases the grain yield of corn because grain filling period was longer which accelerated the better absorption of nutrients. Tabri and Akil (2010) reported that higher level of potassium uptake made faster silk maturity. The early silking accelerates life out tassel and increased grain yield of corn from a unit area of land. Due to early silking, grain filling period was longer and made better absorption of nutrients.

Table 1. Plant growth attributes as influenced by foliar application of potassium (average of two years data).

\begin{tabular}{|c|c|c|c|}
\hline Treatments & $\begin{array}{l}\text { Plant height } \\
\text { (cm) }\end{array}$ & $\begin{array}{l}\text { Time to } 50 \% \text { pollen shedding } \\
\text { (days) }\end{array}$ & $\begin{array}{l}\text { Time to } 50 \% \text { silking } \\
\text { (days) }\end{array}$ \\
\hline Control (no $\mathrm{K}_{2} \mathrm{O}$ application) & $121 \mathrm{e}$ & $60.0 \mathrm{a}$ & $61.3 \mathrm{a}$ \\
\hline Soil application of $75 \mathrm{~kg} \mathrm{~K}_{2} \mathrm{O} \mathrm{ha}{ }^{-1}$ & $153 \mathrm{bc}$ & $57.0 \mathrm{~b}$ & $59.0 \mathrm{bc}$ \\
\hline Foliar spray of $1 \% \mathrm{~K}_{2} \mathrm{O}$ & $165 \mathrm{~b}$ & $54.0 \mathrm{c}$ & $55.7 \mathrm{~d}$ \\
\hline Foliar spray of $2 \% \mathrm{~K}_{2} \mathrm{O}$ & $181 \mathrm{a}$ & $53.3 \mathrm{c}$ & $54.7 \mathrm{~d}$ \\
\hline Foliar spray of $3 \% \mathrm{~K}_{2} \mathrm{O}$ & $187 \mathrm{a}$ & $53.0 \mathrm{c}$ & $54.7 \mathrm{~d}$ \\
\hline Fertigation of $75 \mathrm{~kg} \mathrm{~K}_{2} \mathrm{O} \mathrm{ha}{ }^{-1}$ & $136 \mathrm{~d}$ & $59.3 \mathrm{a}$ & $59.7 \mathrm{~b}$ \\
\hline Split application of $75 \mathrm{~kg} \mathrm{~K}_{2} \mathrm{O} \mathrm{ha}{ }^{-1}$ & $150 \mathrm{c}$ & $56.3 \mathrm{~b}$ & $58.3 \mathrm{c}$ \\
\hline $\operatorname{LSD}(P \leq 0.05)$ & 12.1 & 1.24 & 1.27 \\
\hline
\end{tabular}

Treatment means in each parameter / column bearing different letter(s) have statistically significant difference $(P \leq 0.05)$ among them.

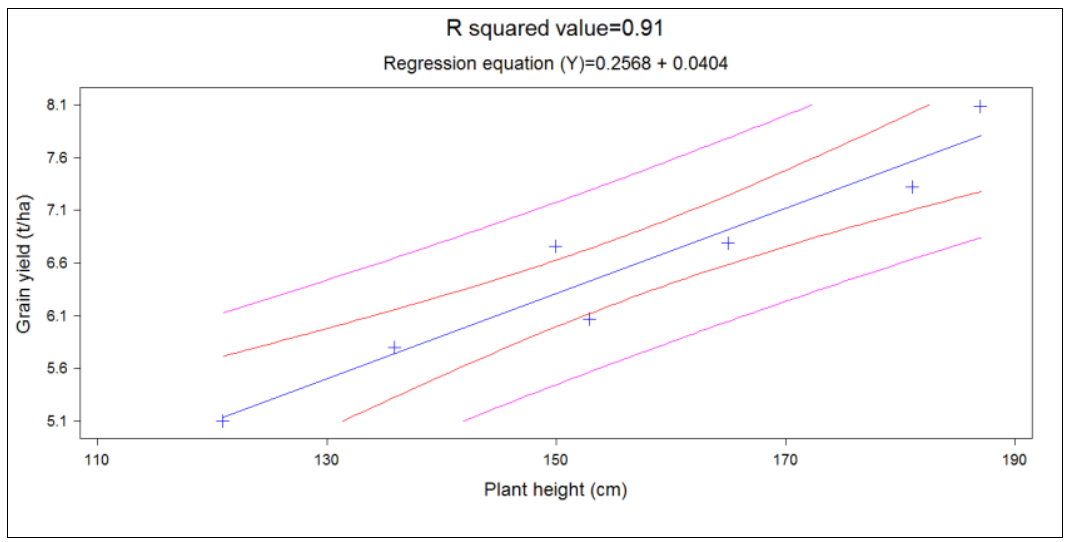

Figure 1. Relationship between the grain yield and plant weight of maize.

\section{Yield attributes}

Data for grain yield, biological yield, 1000 gain weight, grain number per row, grain weight per ear of maize under different potassium treatments revealed significant differences but year's effect was nonsignificant except for number of grains row $^{-1}$ (Table 2). All the foliar potassium treatments were increased the grain yield as compared to soil applied fertilizers and also exhibited the linear relationship (Figure 2). Soil application of potassium also showed significant results but less than with all foliar sprays, among soil applied split soil application of potassium surpassed others for all yield attributes. All foliar sprays at emergence of $7^{\text {th }}$ leaf and tasseling stage surpassed fertigation as well as soil applied potassium for 1000 grain weight, grain number per row and grain weight per row as shown in figure 3 . Efficiency in the yield attributes of maize might be due to foliar spray of $\mathrm{K}_{2} \mathrm{SO}_{4}$ attributed to accelerated availability of $\mathrm{N}$ and other trace elements in the plant structure, more chlorophyll and greater accumulation of protein in plants and efficient translocation of assimilates to reproductive parts. Farooqi et al. (2012) reported that foliar spray @ $1 \% \mathrm{~K}_{2} \mathrm{O}$ at reproductive stage increased the grain yield under normal and drought conditions due to more efficient and timely availability to crop plants. Spray @ 6.0\% $\mathrm{K}_{2} \mathrm{O}$ could produce yield of rice comparable to the yield obtained with the soil application of $\mathrm{K}_{2} \mathrm{O} @ 50 \mathrm{~kg} \mathrm{ha}^{-1}$ (Ali et al., 2007). Grain yield increased by potassium fertilizer because of improving the enzymes activity in the plant, which leads to easy translocation of photosynthates 
from leaf to grain (Hussein, 2005; Mesbah, 2009; Hasina et al., 2011). Abdi et al. (2002) reported that foliar spray of potassium increased 1000 grain weight due to more availability of nutrients which increased the enzyme activation, resulted in easily nutrients partitioning from leaf to grain but soil applied fertilizers exhibited the loss of nutrients via leaching and volatilization. Higher uptake of $\mathrm{K}$ significantly enhanced the number of grains row $^{-1}$
(Grzebisz et al., 2003). Sharma et al. (2005) reported that potassium increased the grain weight ear $^{-1}$. Aladakatti et al. (2011) resulted that boll weight increased by recommended dose of NPK to soil plus foliar application @ 1.0\% muriate of potash (MOP) each at early and peak boll formation stage. Higher cotton yield was produced due to timely and efficient utilization of nutrients via foliar spray that limit the loss of soil applied fertilizer.

Table 2. Grain yield attributes as influenced by foliar application of potassium (average of two years data).

\begin{tabular}{|c|c|c|c|c|c|}
\hline Treatments & $\begin{array}{l}\text { Grain } \\
\text { yield } \\
\left(\mathrm{t} \mathrm{ha}^{-1}\right)\end{array}$ & $\begin{array}{l}\text { Biological } \\
\text { yield } \\
\left(\mathrm{t} \mathrm{ha}^{-1}\right)\end{array}$ & $\begin{array}{l}1000 \text { grain } \\
\text { weight } \\
\text { (g) }\end{array}$ & $\begin{array}{l}\text { Grain count } \\
\left(\# \text { row }^{-1}\right)\end{array}$ & $\begin{array}{l}\text { Grain weight in } \mathrm{g} \\
\left(\mathrm{g} \mathrm{row}^{-1}\right)\end{array}$ \\
\hline Control (no $\mathrm{K}_{2} \mathrm{O}$ application) & $5.10 \mathrm{e}$ & $8.11 \mathrm{e}$ & $241 \mathrm{e}$ & $25.9 \mathrm{f}$ & $171 \mathrm{~d}$ \\
\hline $\begin{array}{l}\text { Soil application of } 75 \mathrm{~kg} \mathrm{~K}_{2} \mathrm{O} \\
\mathrm{ha}^{-1}\end{array}$ & $6.07 \mathrm{~d}$ & $12.0 \mathrm{c}$ & $285 \mathrm{c}$ & $28.9 \mathrm{~d}$ & $191 \mathrm{c}$ \\
\hline Foliar spray of $1 \% \mathrm{~K}_{2} \mathrm{O}$ & $6.78 \mathrm{c}$ & $12.6 \mathrm{c}$ & $298 \mathrm{c}$ & $30.1 \mathrm{c}$ & $229 \mathrm{~b}$ \\
\hline Foliar spray of $2 \% \mathrm{~K}_{2} \mathrm{O}$ & $7.32 \mathrm{~b}$ & $14.0 \mathrm{~b}$ & $316 \mathrm{~b}$ & $33.1 \mathrm{~b}$ & $234 \mathrm{ab}$ \\
\hline Foliar spray of $3 \% \mathrm{~K}_{2} \mathrm{O}$ & $8.08 \mathrm{a}$ & $15.0 \mathrm{a}$ & $356 \mathrm{a}$ & $35.1 \mathrm{a}$ & $248 \mathrm{a}$ \\
\hline Fertigation of $75 \mathrm{~kg} \mathrm{~K}_{2} \mathrm{O} \mathrm{ha}{ }^{-1}$ & $5.80 \mathrm{~d}$ & $10.3 \mathrm{~d}$ & $264 \mathrm{~d}$ & $27.1 \mathrm{e}$ & $167 \mathrm{~d}$ \\
\hline $\begin{array}{l}\text { Split application of } 75 \mathrm{~kg} \mathrm{~K}_{2} \mathrm{O} \\
\mathrm{ha}^{-1}\end{array}$ & $6.76 \mathrm{c}$ & $12.3 \mathrm{c}$ & $296 \mathrm{c}$ & $29.6 \mathrm{~cd}$ & $204 c$ \\
\hline $\operatorname{LSD}(P \leq 0.05)$ & 0.47 & 0.67 & 15.9 & 0.942 & 17.7 \\
\hline
\end{tabular}

Treatment means in each parameter / column bearing different letter(s) have statistically significant difference $(P \leq 0.05)$ among them.

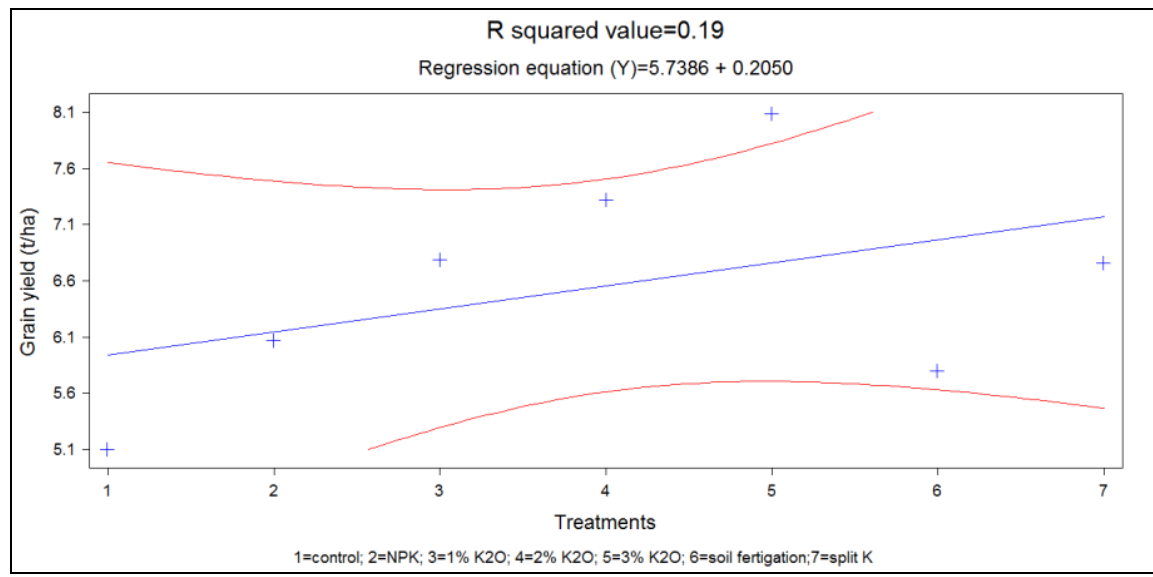

Figure 2. Effect of different potassium treatments on grain yield of maize.

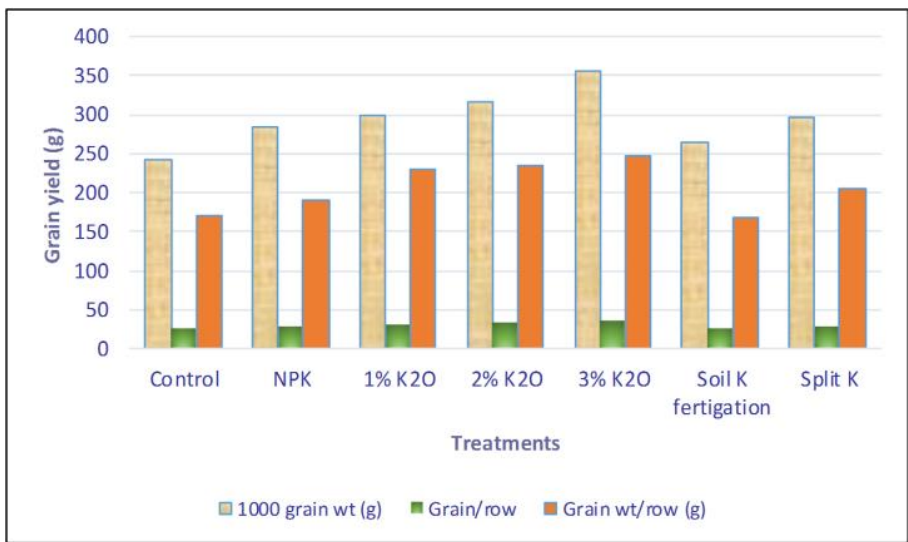

Figure 3. Effect of different potassium foliar treatments on yield attributes of maize. 


\section{Physiological attributes}

There were significant differences in crop growth rate of hybrid maize under various potassium treatments (Table 3). Foliar spray of $3 \% \mathrm{~K}_{2} \mathrm{O}$ recorded higher CGR $\left(70.3 \mathrm{gm} \mathrm{m}^{-2}\right.$ day $\left.^{-1}\right)$ which was at par with $2 \% \mathrm{~K}_{2} \mathrm{O}$ foliar. There were non-significant difference between fertigation of K@ $95 \mathrm{~kg} \mathrm{ha}^{-1}$ and split soil applied potassium. Better crop growth may has been in the result of proper photosynthetic efficiency owing to application of foliar potassium. Crop growth rate showed a direct relationship with dry matter accumulation, and higher CGR under different potassium foliar sprays were exhibited. With time, it reached to its maximum value and showed statistically significant variation under different potassium treatments (45-65 days after sowing) and after that declined up to final harvest of crop. Potassium treatments significantly affected the net assimilation rate, photosynthetic rate and transpiration rate (Table 3). Net assimilation rate exhibited similar trend as CGR under the foliar application of potassium. Higher net assimilation rate of maize was recorded in plots treated with foliar sprays and split dose of potassium as compared to soil application and fertigation of potassium. Highest photosynthetic rate $\left(23.6 \mu \mathrm{mol} \mathrm{m}^{-2} \mathrm{~s}^{-1}\right)$ was recorded with $3 \% \mathrm{~K}_{2} \mathrm{O}$ spray which was statistically at par with $1 \% \mathrm{~K}_{2} \mathrm{O}$ spray. Higher efficiency of photosynthates to reproductive parts by improving the internal water potential through foliar potassium, and also supplied for effective ears with proper grain filling period resulted in optimum grain yield production (Figure 4). Grain yield and photosynthetic rate of maize plants have same increasing and decreasing trend, higher efficiency of photosynthetic pigments may lead to higher grain production. Higher transpiration rate were recorded under control (no potassium) treatment but lowest transpiration rate was examined in split soil application of potassium. All foliar treated plants showed less transpiration rate as compared to control and soil applied potassium. Damon and Rengel (2008) stated that higher crop growth rate might be exhibited due to higher photosynthetic efficiency in leaves and supplied emerging cobs with existing photosynthates for proper filling, producing higher yield. Akram et al. (2010) reported that potassium accelerated the net assimilation rate. Tabatabaii et al. (2011) explained that photosynthetic rate was increased by increasing the potassium uptake level. Ihsan et al. (2013) stated that foliar applied potassium at $250 \mathrm{mg}$ $\mathrm{L}^{-1}$ increased the photosynthetic efficiency of mung bean (Vigna radiata L.) crop under drought conditions and potassium foliar spray significantly increased the photosynthetic efficiency of mungbean plants under drought conditions (Thalooth et al., 2006). Zareian et al. (2013) stated that transpiration rate increased by increasing the drought stress and potassium foliar spray effectively cope the drought stress, also manage the internal water potential of crop.

Table 3. Physiological attributes as influenced by foliar application of potassium (average of two years data)

\begin{tabular}{|c|c|c|c|c|}
\hline Treatments & $\begin{array}{l}\text { Crop growth } \\
\text { rate } \\
\left(\mathrm{g} \mathrm{m}^{-2} \mathrm{day}^{-1}\right)\end{array}$ & $\begin{array}{l}\text { Net assimilation } \\
\text { rate } \\
\left(\mathrm{g} \mathrm{m}^{-2} \mathrm{day}^{-1}\right)\end{array}$ & $\begin{array}{l}\text { Photosynthetic } \\
\text { rate } \\
\left(\mu \mathrm{mol} \mathrm{m}{ }^{-2} \mathrm{~s}^{-1}\right)\end{array}$ & 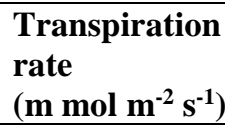 \\
\hline Control (no $\mathrm{K}_{2} \mathrm{O}$ application) & $46.9 \mathrm{~d}$ & $4.74 \mathrm{~b}$ & $14.6 \mathrm{~d}$ & $5.02 \mathrm{a}$ \\
\hline $\begin{array}{l}\text { Soil application of } 75 \mathrm{~kg} \mathrm{~K}_{2} \mathrm{O} \\
\mathrm{ha}^{-1}\end{array}$ & $57.7 \mathrm{bc}$ & $4.90 \mathrm{~b}$ & $23.0 \mathrm{ab}$ & $5.07 \mathrm{a}$ \\
\hline Foliar spray of $1 \% \mathrm{~K}_{2} \mathrm{O}$ & $65.3 \mathrm{ab}$ & $5.95 \mathrm{a}$ & $23.0 \mathrm{a}$ & $4.63 \mathrm{ab}$ \\
\hline Foliar spray of $2 \% \mathrm{~K}_{2} \mathrm{O}$ & $70.2 \mathrm{a}$ & $6.37 \mathrm{a}$ & $20.7 \mathrm{~b}$ & $4.16 \mathrm{~b}$ \\
\hline Foliar spray of $3 \% \mathrm{~K}_{2} \mathrm{O}$ & $70.3 \mathrm{a}$ & $6.19 \mathrm{a}$ & $23.6 \mathrm{a}$ & $4.40 \mathrm{ab}$ \\
\hline Fertigation of $75 \mathrm{~kg} \mathrm{~K}_{2} \mathrm{O} \mathrm{ha}{ }^{-1}$ & $50.3 \mathrm{~cd}$ & $5.16 \mathrm{~b}$ & $14.0 \mathrm{~d}$ & $4.06 \mathrm{~b}$ \\
\hline $\begin{array}{l}\text { Split application of } 75 \mathrm{~kg} \mathrm{~K}_{2} \mathrm{O} \\
\mathrm{ha}^{-1}\end{array}$ & $53.1 \mathrm{~cd}$ & $6.01 \mathrm{a}$ & $17.9 \mathrm{c}$ & $3.13 \mathrm{c}$ \\
\hline $\operatorname{LSD}(P \leq 0.05)$ & 7.99 & 0.606 & 2.42 & 0.858 \\
\hline
\end{tabular}

Treatment means in each parameter / column bearing different letter(s) have statistically significant difference ( $\mathrm{P} \leq 0.05)$ among them.

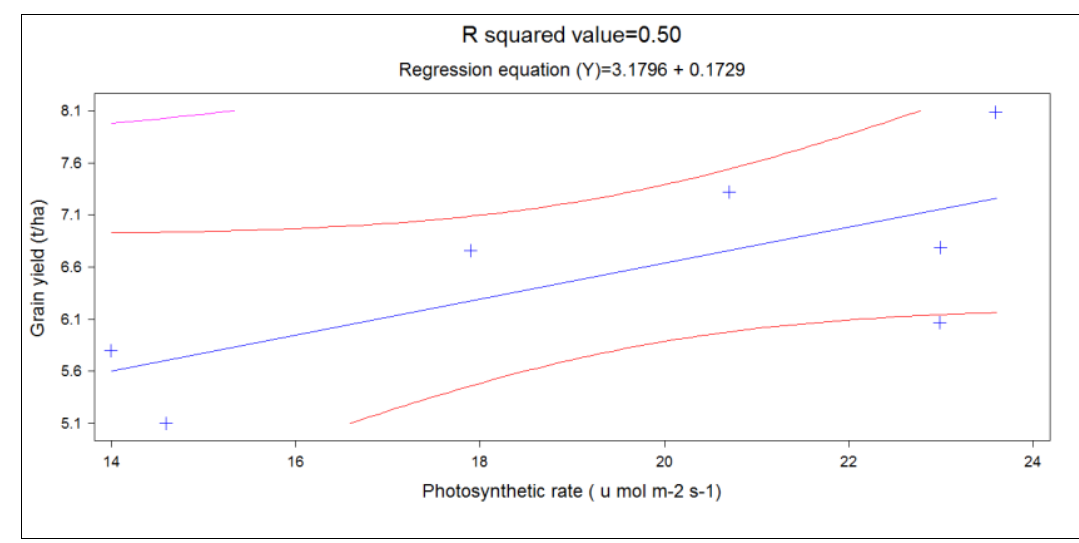

Figure 4. Relationship between the grain yield and photosynthetic rate of maize. 


\section{Grain quality attributes}

Data showed that grain protein and starch contents were significantly affected under potassium treatments in maize hybrid (Table 4). All potassium foliar sprays exhibited greater grain protein and starch contents than fertigation and soil application of potassium. Application of foliar $\mathrm{K} @ 3 \% \mathrm{~K}_{2} \mathrm{O}$ showed grain protein $(7.77 \%)$ and starch contents $(69.9 \%)$ which were statistically at par with those at $2 \% \mathrm{~K}_{2} \mathrm{O}$ sprays. John and Lester (2011) reported that potassium foliar spray increased crude protein and starch contents in grains due to the greater availability of nutrients to cereals. Meanwhile, grain protein contents decreased under the water stress especially at reproductive stages but potassium fertilizers cope the drought stress and improving the grain quality as well as yield attributes (Minjian et al., 2007).

Table 4. Grain quality attributes as influenced by foliar application of potassium (average of two years data)

\begin{tabular}{lll}
\hline Treatments & Grain protein contents (\%) & Grain starch contents (\%) \\
\hline Control (no $\mathrm{K}_{2} \mathrm{O}$ application) & $6.74 \mathrm{c}$ & $67.4 \mathrm{c}$ \\
& & \\
Soil application of $75 \mathrm{~kg} \mathrm{~K}_{2} \mathrm{O} \mathrm{ha}^{-1}$ & $7.14 \mathrm{~b}$ & $68.0 \mathrm{bc}$ \\
Foliar spray of $1 \% \mathrm{~K}_{2} \mathrm{O}$ & & $69.4 \mathrm{a}$ \\
Foliar spray of $2 \% \mathrm{~K}_{2} \mathrm{O}$ & $7.19 \mathrm{~b}$ & $69.6 \mathrm{a}$ \\
Foliar spray of $3 \% \mathrm{~K}_{2} \mathrm{O}$ & $7.62 \mathrm{a}$ & $69.9 \mathrm{a}$ \\
Fertigation of $75 \mathrm{~kg} \mathrm{~K}_{2} \mathrm{O} \mathrm{ha}^{-1}$ & $7.77 \mathrm{a}$ & $67.6 \mathrm{c}$ \\
Split application of $75 \mathrm{~kg} \mathrm{~K}_{2} \mathrm{O} \mathrm{ha}^{-1}$ & $6.79 \mathrm{c}$ & $68.5 \mathrm{~b}$ \\
$\mathrm{LSD}(P \leq 0.05)$ & $7.17 \mathrm{~b}$ & 0.679 \\
\hline Treatment means in each parameter / column bearing different letter(s) have statistically significant difference $(P \leq 0.05)$ among them.
\end{tabular}

\section{Economics of fertilizer use}

All foliar sprays viz 1,2 and 3 per cent at $7^{\text {th }}$ leaf and tasseling stage increased the financial returns relative to that achieved without them (Table 5). Economic analysis was carried out in terms of benefit cost ratio (BCR). Higher BCR (4.75) was recorded with treatment fertilized by foliar application of $3 \% \mathrm{~K}_{2} \mathrm{O}$, followed by $2 \% \mathrm{~K}_{2} \mathrm{O}$ (4.31) and $1 \% \mathrm{~K}_{2} \mathrm{O}$ (3.91). Least BCR (1.81) was found $\mathrm{K}$ fertigation, followed by soil application of potassium (2.62) and control (2.61). Farooqi et al. (2012) reported that soil applied fertilizers plus potassium foliar spray increased the economic grain yield and net benefit cost ratio. Abdul et al. (2012) concluded that foliar spray application of $\mathrm{KNO}_{3}$ at $0.5 \%$ and $1 \%$ solution had greater benefits over soil application resulted from increased potassium uptake efficiency of rice crop.

Table 5. Benefit cost ratio as influenced by soil and foliar application of potassium on hybrid maize.

\begin{tabular}{|c|c|c|c|c|c|c|c|}
\hline $\begin{array}{l}\text { Inputs / } \\
\text { Economic } \\
\text { Parameters }\end{array}$ & $\begin{array}{l}\text { Control (no } \\
\mathrm{K}_{2} \mathrm{O} \\
\text { application) }\end{array}$ & $\begin{array}{l}\text { Soil } \\
\text { application of } \\
75 \mathrm{~kg} \mathrm{~K}_{2} \mathrm{O} \\
\mathrm{ha}^{-1}\end{array}$ & $\begin{array}{l}\text { Foliar } \\
\text { spray of } \\
1 \% \mathrm{~K}_{2} \mathrm{O}\end{array}$ & $\begin{array}{l}\text { Foliar } \\
\text { spray of } \\
2 \% \mathrm{~K}_{2} \mathrm{O}\end{array}$ & $\begin{array}{l}\text { Foliar } \\
\text { spray of } \\
3 \% \mathrm{~K}_{2} \mathrm{O}\end{array}$ & $\begin{array}{l}\text { Fertigation of } \\
75 \mathrm{~kg} \mathrm{~K}_{2} \mathrm{O} \\
\mathrm{ha}^{-1}\end{array}$ & $\begin{array}{l}\text { Split } \\
\text { application of } \\
75 \mathrm{~kg} \mathrm{~K}_{2} \mathrm{O} \mathrm{ha}\end{array}$ \\
\hline Urea & 9,672 & 9,672 & 9,672 & 9,672 & 9,672 & 9,672 & 9,672 \\
\hline DAP & 17,750 & 17,750 & 17,750 & 17,750 & 17,750 & 17,750 & 17,750 \\
\hline SOP & N.A. & 13,200 & 382 & 765 & 1,447 & 26,400 & 13,200 \\
\hline $\begin{array}{l}\text { Total cost } \\
\left(\mathrm{Rs} \mathrm{ha}^{-1}\right)\end{array}$ & 26,330 & 26,330 & 26,330 & 26,330 & 26,330 & 26,330 & 26,330 \\
\hline $\begin{array}{l}\text { Total cost } \\
\left(\mathrm{Rs} \mathrm{ha}^{-1}\right)\end{array}$ & 53,752 & 66,952 & 54,134 & 54,517 & 55,199 & 80,152 & 66,952 \\
\hline $\begin{array}{l}\text { Grain yield } \\
\left(\mathrm{t} \mathrm{ha}^{-1}\right)\end{array}$ & 5.10 & 6.07 & 6.77 & 7.32 & 8.08 & 5.79 & 6.75 \\
\hline $\begin{array}{l}\text { Grain yield } \\
\text { revenue } \\
\left(\mathrm{Rs} \mathrm{ha}^{-1}\right)\end{array}$ & 153,270 & 182,163 & 203,184 & 219,690 & 242,553 & 173,853 & 202,536 \\
\hline $\begin{array}{l}\text { Fodder yield } \\
\left(\mathrm{t} \mathrm{ha}^{-1}\right)\end{array}$ & 8.11 & 12.0 & 12.6 & 14.0 & 15.0 & 10.3 & 12.3 \\
\hline $\begin{array}{l}\text { Fodder yield } \\
\text { revenue } \\
\left(\mathrm{kg} \mathrm{ha}^{-1}\right)\end{array}$ & 40,555 & 59,955 & 62,710 & 69,720 & 74,645 & 51,675 & 61,710 \\
\hline $\begin{array}{l}\text { Gross revenue } \\
\left(\mathrm{Rs} \mathrm{ha}^{-1}\right)\end{array}$ & 193,825 & 242,118 & 265,894 & 289,410 & 317,198 & 225,528 & 264,246 \\
\hline $\begin{array}{l}\text { Net benefit } \\
\left(\mathrm{Rs} \mathrm{ha}^{-1}\right)\end{array}$ & 140,073 & 175,166 & 211,760 & 234,893 & 261,999 & 145,376 & 197,294 \\
\hline $\begin{array}{l}\text { Benefit cost } \\
\text { ratio }\end{array}$ & 2.61 & 2.62 & 3.91 & 4.31 & 4.75 & 1.81 & 2.95 \\
\hline
\end{tabular}




\section{CONCLUSION}

This study indicates that foliar spray of $\mathrm{K}_{2} \mathrm{O}$ at $3 \%$ concentration (equivalent to $13 \mathrm{~kg} \mathrm{~K}_{2} \mathrm{SO}_{4} \mathrm{ha}^{-1}$ ) performs better and fulfills potassium requirement of the crop as compared to 1 and $2 \% \mathrm{~K}_{2} \mathrm{O}$ spray. Further, Split soil application of potassium surpasses soil applied and fertigation of potassium under rain-fed conditions for majority of the growth and yield attributes of maize. Therefore, it is recommended that potassium should be applied preferably through foliar spray, or if unavoidable its soil application should be made in two splits. Potassium fertilizer foliar spray and split application also renders greater economic returns as compared to traditional soil application and fertigation practices.

\section{ACKNOWLEDGEMENTS}

This research work was supported by National Agriculture Research Centre Islamabad, Pakistan. We would like to thanks Maize, Sorghum and Millet Program for kindly supply all required research materials and experimental field area.

\section{LITERATURE CITED}

Abdi, M., G. Nour-Mohamedi and Golchin, A. 2002. The influence of foliar nutrition of urea and potassium chloride on grain yield, grain protein contents, yield components and leaf relative water content of Sardari wheat under rainfed conditions. J. Agric. Sci., 8(1): 29-38.

Akram, M., M.Y. Ashraf, R. Ahmad, M. Rafiq, I. Ahmad and J. Iqbal. 2010. Allometry and yield components of maize (Zea mays L.) hybrids to various potassium levels under saline conditions. Archives of Biol. Sci., 62(4): 1053-1061.

Aladakatti, Y.R., S.S. Hallikeri, R.A. Nandagavi, N.E. Naveen, A.Y. Hugar and D. Blaise. 2011. Yield and fiber qualities of hybrid cotton (Gossypium hirsutum L.) as influenced by soil and foliar application of potassium. Karnataka J. Agric. Sci., 24(2): 133-136.

Ali, A., I.A. Mahmood, F. Hussain and M. Salim. 2007. Response of rice to soil and foliar application of $\mathrm{K}_{2} \mathrm{SO}_{4}$ fertilizer. Sarhad J. Agric., 23(4): 847-850.

Ali, A., M. Salim, M.S. Zia, I.A. Mahmood and A. Shahzad. 2005b. Performance of rice as affected by foliar application of different $\mathrm{K}$ fertilizer sources. Pak. J. Agric. Sci., 42(1-2): 38-41.

Amal, G.A., M.M. Tawfik and M.S. Hassanein. 2011. Foliar feeding of potassium and urea for maximizing wheat productivity in sandy soil. Aust. J. Basic \& Applied Sci., 5(5): 1197-1203.

Anonymous. 2006. Agricultural Statistics of Pakistan. Government of Pakistan, Islamabad.

Bukhsh, M.A.A.H.A., M. Usman, E. Ullah and E. A. Warriach. 2003. Effect of different phosphorus levels on the growth and yield of two cultivars of maize (Zea mays L.). Int. J. Agric. Biol., 5: 632-634.

Chaudhary, A.R. 1993. Maize in Pakistan. Punjab Agricuture Research Cordination Board, University of Agriculture, Faisalabad, Pakistan.
Damon, P.M. and Z. Rengel. 2008. Crops and genotypes differ in efficiency of potassium uptake and use. Physiologia Plantarum, 133(4): 624-36.

Eichert, T. and J. Burkhardt. 2001. Quantification of stomatal uptake of ionic solutes using a new model system. J. Exp. Bot., 52: 771-781.

Farooqi, M.Q.U., R. Ahmad, E.A. Wariach and M. Arfan. 2012. Effect of supplemental foliar applied potassium on yield and grain quality of autumn planted maize (Zea mays L.) under water stress. J. Food, Agric. Vet. Sci., 2(3): 8-12.

Grzebisz, W., A. Baer, P. Baróg, W. Szczepaniak and J. Potarzycki. 2001-2003. Effect of nitrogen and potassium fertilizing systems on maize grain yield. University of Life Sciences, Poznan, Poland, pp: 4546.

Hasina, G., A. Said, B. Saeed and K. Ahmad. 2011. Response of yield and yield components of wheat towards foliar spray of nitrogen, potassium and zinc. Asian Res. Pub. Net., 6(2): 23-2.

Hunt, R., D. R. Causton, B. Shipley and A. P. Askew. 2002. "A modern tool for classical plant growth analysis," Annals of Botany, 90(4): 485-488.

Hurburgh, C.R.J. 1989. The value of quality to new and existing corn users. American Society of Agric., Eng. paper 89-6016. The Society: St. Joseph, MI.

Hussein, S.M.A. 2005. Effect of supplemental irrigation, seeding rate and foliar of potassium, macro and microelements on wheat activity under the rainfed conditions. Bulletin of Faculty of Agriculture, Cairo University, Egypt, 56(3): 431-453.

Ihsan, M.Z., N. Shahza, S. Kanwal, M. Naeem, A. Khaliq, F.S. El-Nakhlawy and A. Matloob. 2013. Potassium as foliar supplementation mitigates moisture induced stresses in mung bean (Vigna radiata L.) as revealed by growth, photosynthesis, gas exchange capacity and zinc analysis of shoot. Inter. J. Agro. Plant Prod., 4(5): 3828-3835.

John, L.J. and G.E. Lester. 2011. Effect of foliar potassium fertilization and source on cantaloupe yield and quality. Better Crops, 95(1): 13-15.

Juliano, B.O. 1991. A simplified assay for maize analysis. Cereal Sci. Today, 16(2): 334-340.

Abdul, W.K., R.A. Mann, M. Saleem and A. Majeed. 2012. Comparative rice yield and economic advantage of foliar $\mathrm{KNO}_{3}$ over soil applied $\mathrm{K}_{2} \mathrm{SO}_{4}$. Pak. J. Agri. Sci., 49(4): 481-484.

Malik, D. M., R.A. Chaudhry and G. Hussan. 1989. Crop response to potash application in the Punjab. In: Role of Potassium in improving fertilizer use efficiency. Proceedings of the Workshop on the Role of Potassium in improving fertilizer use efficiency, held in Islamabad, 21-22 March 1987. National Fertilizer Development Center, Planning and Development Division; pp.187-190.

Mangel, K. and E.A. Kirkby. 1987. Principles of plant nutrition. Inst. Potash Bern, Switzerland, pp: 5-100.

Mesbah, E.A.E. 2009. Effect of irrigation regimes and foliar spraying of potassium on yield, yield 
components and water use efficiency of wheat (Triticum aestivum L.) in sandy soils. World J. Agric. Sci., 5(6): 662-669.

Minjian, C., Y. Haiqui, Y. Hongkui and J. Chungi. 2007. Difference in tolerance to potassium deficiency between maize inbred lines. Plant Prod. Sci., 10(1): 42-45.

Montgomery, D.C. 2001. Design and Analysis of Experiments. 5th ed., Wiley, New York.

NFDC. 2005. In: Fertilizer Use Related Statistics. National Fertilizer Development Centre, Planning Division, Government of Pakistan, Islamabad.

Ranjha, A. M., A. Jabbar and R.H. Qureshi. 1990. Effect of amount and type of clay minerals on potassium fixation in some alluvial soils of Pakistan. Pak. J. Agri. Sci., 27(3): 187-192.

Sharma, S., E. Duveiller, R. Basnet, C.B. Karki and R.C. Sharma. 2005. Effect of potash fertilization on Helminthosporium leaf blight severity in wheat, and associated increases in grain yield and kernel weight. Field Crops Research, 93(1): 142-150.

Tabatabaii, E.S., M. Yarnia, K. Benam and Tabrizi, F.M. 2011. Effect of potassium fertilizer on corn yield (Jet acv.) under drought stress condition. AmericanEurasian J. Agric. Environ. Sci., 10(2): 257-263.

Tabri, F. and M. Akil. 2010. Effect of Potassium on the Growth, Production and Quality of F1 hybrid Maize. Indonesian Cereals Research Institute. In: Proceedings of International Maize Conference, pp: 261-263.

Thalooth, A.T., M.M. Tawfik and H.M. Mohamed. 2006. A comparative study on the effect of foliar application of zinc, potassium and magnesium on growth, yield and some chemical constituents of mungbean plants grown under water stress conditions. World J. Agric. Sci., 2(1): 37-46.

William, T.P. 2008. Potassium influences on yield and quality production for maize. Physio. Plantarum, 133: 670-681.

Witt, C. and J.M.C.A. Pasuquin. 2007. Maize in Asia and global demand II. International Fertilizer Correspondent, 14: (5-6).

Zareian, A., H.H.S. Abad, A. Hamidi, G.N. Mohammadi and S.A. Tabatabaei. 2013. Effect of drought stress and potassium foliar application on some physiological indices of three wheat (Triticum aestivum L.) cultivars. Annals of Biological Research, 4(5): 71-74. 